\title{
Technology Innovation Transition Strategy to Achieve Indonesian Local Millennial Customer Satisfaction in Using Digital Facilities
}

\author{
${ }^{1}$ Debby Christyna Marina \\ Student of Communication Faculty \\ Magister of Communication at Mercu Buana University \\ Jakarta, Indonesia
}

\begin{abstract}
This study aims to analyze how the use of digital facilities as a form of transition to technological innovation for Indonesia's local millennial. Technology Innovation Transition is an action to change the old work system to a new work system, starting from the conventional one to more sophisticated technology. In this context, the transition of technological innovation has become part of the customer service industry, one of the biggest users of digital facilities is local millennial, in this study the researchers narrowed the scope of millennial discussion, researchers focused more on Indonesian local millennial. The theory used to analyze is the theory of innovation and other supporting theories. This study uses a qualitative method with a case study approach and data collection techniques by means of in-depth interviews with informants and field observations to answer the results of the research. The results of the study show that certain levels of local Indonesian millennial capabilities have not really been able to fully adapt to sophisticated technological innovations as a form of transition.
\end{abstract}

Keywords:- Digital, Disruptive Innovation, Millennial, Social Stratification, Transition, New Media.

\section{INTRODUCTION}

Transition is a period of change that is marked by a change from the initial phase to the new phase. Where at the time of transition the situation was not yet stable, people had not really abandoned old habits and had not fully adapted to new things. For example work systems that are transitioning to digital technology habits, namely the shift from traditional work culture to new digital culture, from conventional work systems to work systems that use higher technology.

Meanwhile, transitional societies are people who experience changes from one community to another. These people are starting to leave their old culture but have not yet fully adopted their new culture. Transition or transition is a positive and natural thing to happen as long as it is directed to a good thing and is not done with half measures that still cannot leave the old one and have not been fully able to use the new one.

\author{
${ }^{2}$ Ahmad Mulyana \\ Lecturer of Communication Faculty \\ Magister of Communication at Mercu Buana University \\ Jakarta, Indonesia
}

Technology transition illustrates how this technological innovation occurs and is involved in society. Along with technological developments, the technology transition considers broader social changes such as the presence of millennial generation with various abilities in using technology.

For a technology to be used, it must be linked to the social structure of human and organizational agencies to meet specific needs. Refers to an infinite net in which organizations, the scientific community, and social practices join. The technological system covers technical and non-technical aspects, and this is a major change in the socio-technical configuration involving at least one new technology when the technology transition occurs.

In a previous study in a national journal entitled Transition of the Indonesian Community Towards an Information Society, it was stated that the Indonesian people were heading to become an information society. It is said so because what the information society says is that people who fully use information technology devices in their lives. Although in fact there are already Indonesian people who use information technology, but it has not yet touched all Indonesian people comprehensively and universally (Rhoni Rodin, 2013).

In another national journal, the Purworejo Regency Transition Strategy from E-Government to Smart City states that the strategy carried out by Purworejo district from e-government to smart city is a system approach. The approach between the elaboration of the policy direction in vision and mission with the service domain on the Garuda Smart City Model. Every policy direction described is associated with smart economy, smart society or smart environment. In addition there is a quick win from the vision and mission aimed at accelerating the achievement of targets towards smart city. Quick win is in the form of developing information technology-based programs that will support the acceleration of Purworejo district towards smart city (M. Murhadi and HM Jumasa, 2019) 


\section{$>$ Technology Development Transition}

In business, strategies determine the scope and direction of an organization's development and how it can achieve competitive strategies (Butterick, 2014). From this explanation it can be said that the strategy is a careful planning that can provide direction regarding the path that must be taken to achieve the goals to be achieved. In this study, researchers used the concept of 6 (six) phases of 6D's of Exponential Growth (Peter Diamandis, 2012) Founder of X-Prize Foundation and Co-Founder, Singularity University.

In the technology transition as explained in the figure below, it reinforces that technology has a fairly rapid development. With so much technology developing, the greater the potential for things - things around can be disrupted. Nowadays, the development of technology and internet media is moving very fast. Increasingly the number of internet users continues to grow. According to the representative of the UN telecommunications agency Hamadoun Toure, the number of internet users in $2011 \mathrm{had}$ reached approximately two billion users. According to the Secretary General of the United Nations International Telecommunications Union (ITU), the number of mobile subscribers has reached the symbolic limit of five billion. In fact, in early 2000 there were only 500 million global mobile subscribers and 250 million internet users (Fadhlya Chandra Kirana).

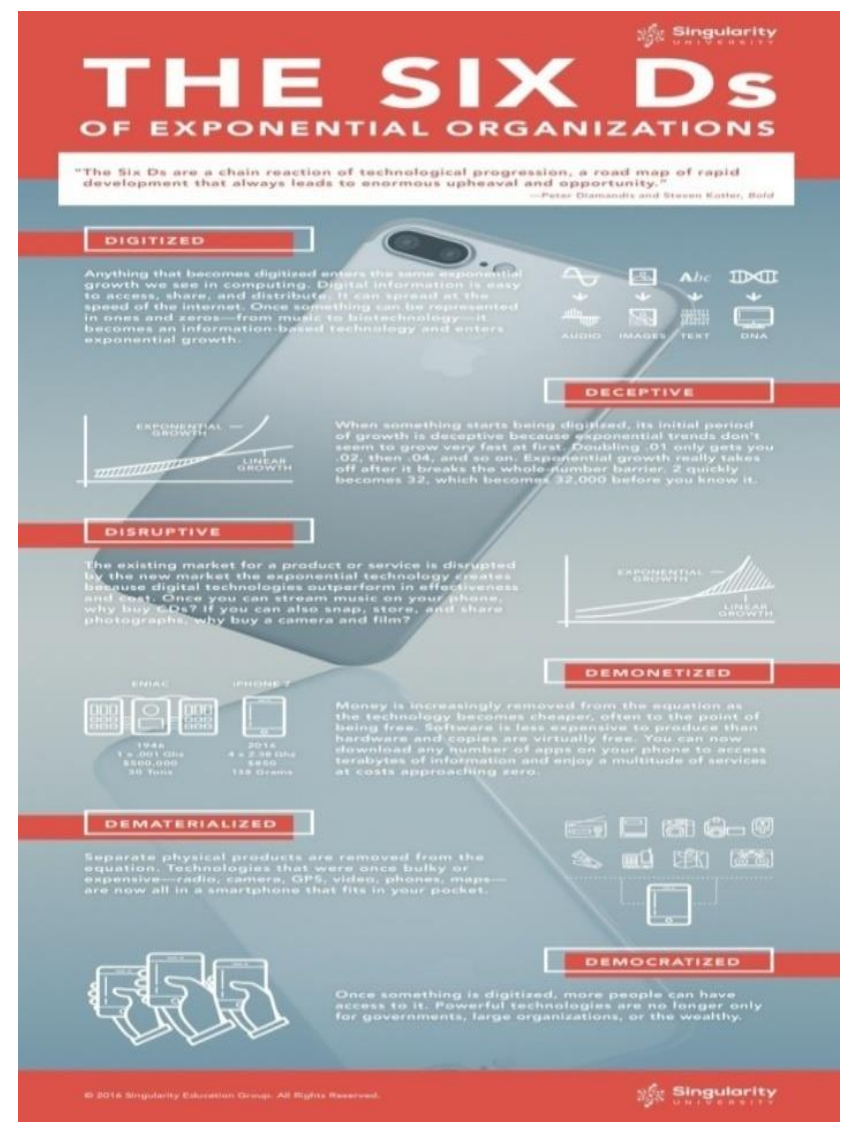

Fig 1: - Six Transitions in Technological Progress Source: www.diamandis.com
The same thing also happened in Indonesia, Indonesia is ranked third in Asia for the largest number of internet users. Although many Indonesians use the internet, not all Indonesians are technology literate. Geographical and economic factors are the cause. Indonesia's vast territory from Sabang to Merauke has caused the distribution of education, economy and even technology to become unequal in each region. In big cities like Jakarta, Surabaya or Bali, it is easy to find people who are using sophisticated smartphones. Whether it's for business, entertainment or prestige.

But it is different with the interior of West Kalimantan or villages in East Nusa Tenggara far from the city center. Television just might not have them let alone how to use the internet or computers they don't understand anymore.

In the progress of information technology there is one tool that can be used to access information globally and that is indeed symptomatic in Indonesian society, namely the internet. Because so swift currents in the world of information technology that (Pry S, 2009) advances in information technology information flows are so swift globalized to all corners of the world including Indonesia so that many people are swept away by the progress of this information technology

One of the facilities that use the internet network is digital information applications, a means used to facilitate the public in obtaining information digitally without limited space and time. The phenomenon of using digital information applications by Indonesian millennial customers at the digital airport lounge Soekarno Hatta International Airport is one interesting thing to be examined from the perspective and perspective of Indonesian local millennial customers. Because the world today cannot be separated from information infrastructure. Therefore, the researcher tries to examine this from the perspective of the ability of local Indonesian millennial customers to adapt to the transition of technological innovation.

\section{THEORITICAL REVIEW}

\section{> Concept of Technology Transition}

Diamandis and Kotler say the 6D's are a chain reaction of technological progression, a road map of rapid development that always leads to enormous upheaval and opportunity (Peter Diamandis, 2012). Diamandis divides technological progress exponentially through 6 phases called the 6D of Exponential Growth, namely Digitalization, Disruption, Deception, Demonetization, Dematerialization, and Democratization

\section{$>$ Disruptive Innovation Theory}

Clayton M. Christensen said that the phenomenon where an innovation changes the existing market or sector by introducing simplicity, convenience, accessibility, and affordability (simplicity, convenience, accessibility, and affordability) where complications of complexity and high costs in the status quo position. Initially, disruptive 
innovations were formed in limited markets that seemed unattractive or unimportant to industries that already existed, but eventually new products or ideas completely redefined the industry. Clayton M. Christensen, 1995). Disruptive innovations usually take certain target market segments that are less desirable or considered less important to market leaders, but their innovations are breakthrough and are able to define the existing system or market.

\section{$>$ Digital Theory (New Media)}

Digital theory is a conceptual understanding of the times of technology and science, from everything that is manual to what is automatic and everything that is complicated becomes more concise. Digital is a complex and flexible method that makes it essential in human life. Digital theory is always associated with the media, because media is something that continues to experience change and development.

\section{$>$ Customer Satisfaction Theory}

Kotler said that customer satisfaction is a feeling of pleasure or disappointment felt by the customer after comparing between something received or obtained with what is expected by the customer where if the reality received is in line with expectations, the customer will be satisfied and if the reality received is not in line with expectations, then the customer will not be satisfied. (Kotler, 2006).

\section{> Techonolgy Savvy (Technology Literacy)}

According to the National Chamber Foundation (NCF, 2013) 75\% are millennials with technology savvy ie those who have high adaptability to developing technologies. Based on research by the Indonesian Internet Service Providers Association (APJII, 2017), it was found that the millennial generation group is the group with the highest percentage of internet use reaching $49.52 \%$. This shows that millennials tend to always use technology in their daily lives. Examples of the use of technology by millennial are very visible when going traveling. The choice of millennial destinations is much influenced by the rating of the place, how photogenic, is there ever an influencer who has been there, rather than coming directly to a new destination.

\section{$>$ Profile of Millennial Generation}

Millennials also often known as generation $\mathrm{Y}$ are a group of demographics after generation $X$ (gene $x$ ). Millennial generation born in 1980-2000 as the birth of this group. Included in the category of millennial generation are young people aged 17-37 this year. Millennial generation is considered special because this generation is very different from the previous generation, especially when it is associated with technology, millennial generation has its own characteristics that they are born when TV has color, cellphones and internet have been introduced slowly but surely . So it's no wonder this generation is very proficient in technology.

\section{TTPE GEERASS MWLENIALINDONESIA}

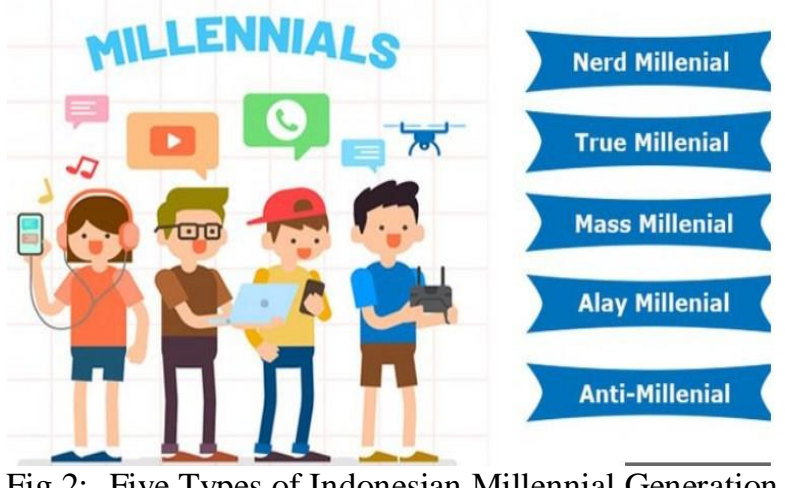

Fig 2:- Five Types of Indonesian Millennial Generation Source: www.alvara-strategic.com

Based on a national research conducted by Alvara Research Center in early 2018 where this survey was conducted on 2,200 respondents throughout Indonesia with an age range between 15-39 years there are five types of Indonesian millennial generation as follows: (1) Millennial Nerd of $7.4 \%$ (2) True Millennial as much as $22.7 \%$ (3) Mass Millennial as much as $41.8 \%$ (4) Alay Millennial as much as $9.3 \%$ (3) Anti-Millennial as much as $18.9 \%$

\section{Social Stratification}

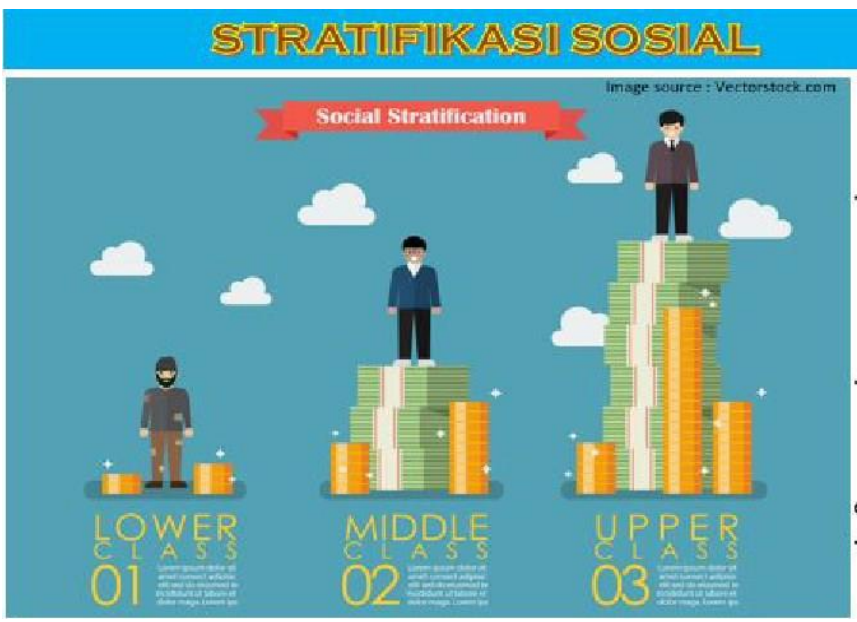

Fig 3:- Social Stratification

Source: Arifin Noor, 2017

This community coating system is often known as social stratification. Broadly speaking the differences that exist in society based on the material owned by someone who is called a social class (social class). According to (Arifin Noor, 2017) divides social class into three groups, as follows: (1) Lower class society is a group that earns income or income in return for their work which is far less than their basic needs. (2) Middle class society is a middle class group usually identified by professionals and business owners and smaller businesses. Usually occupied by people who are mostly at a moderate level (3) Upper Class Society (upper class society). 


\section{RESEARCH METHODS}

\section{$>$ Research methods}

The method used for the title of Technology Innovation Transition Strategy to Achieve Indonesian Local Millennial Customer Satisfaction in Using Digital Facilities is a qualitative research method of case study approach.

\section{Data Type}

Primary data obtained or collected directly by researchers in the field. Secondary data is data obtained or collected by researchers from existing sources.

\section{> Data Collection Techniques}

Data collection techniques by field observation, indepth interviews and documentation in the form of field photographs. Data analysis uses data reduction, data presentation, and drawing conclusions.

\section{FINDINGS AND DISCUSSION}

\section{A. Findings}

During the transition of a work system from work systems that are conventional and analogous to the work system that is more modern and integrated by targeting its market share, namely local Indonesian millennial customers. This research also monitors and observes developments in the field by looking at several levels of technology innovation transition strategies that have been carried out by PT. Angkasa Pura II (Persero) Soekarno Hatta International Airport, researchers take 6 (six) phases of the $6 \mathrm{D}$ exponential technology development process from (Diamandis, 2012) as follows:

\section{$>$ Phase I, Digitalization:}

The phase in which digitization takes place, the transition from offline to online from analog to digital in almost all sectors. The rapid and rapid development of technological innovation is one of the reasons for PT. Angkasa Pura II (Persero) Soekarno Hatta International Airport to improve technological services in all sectors. Where the initial formation of the i-MATE (millennial airport travel experience) T3 digital lounge airport started from which initially only provided counter information and was served by service personnel who are still very conventional and manual, now has switched to digital information services, with this innovation It is expected to become a program that can be made to catch up with the long-standing backwardness in the situation of air transportation services in Indonesia.

\section{$>$ Phase II, Deceptive}

In this phase, when something is experiencing digitalization, the impact is not yet visible, there is no significant development, even many trial errors. As a company engaged in airports, PT. Angkasa Pura II (Persero) Soekarno Hatta International Airport has special advantages, one of which is the protection from the law, so there will be a lack of competition. Therefore PT. Angkasa Pura II (Persero) Soekarno Hatta International Airport is very focused on customer service to achieve customer satisfaction.

Based on the information conveyed by the informants, it can be explained that the weaknesses faced by PT. Angkasa Pura II (Persero) Soekarno Hatta International Airport based on an analysis of the previous situation by looking at the technological conditions, that the initial implementation of digitalization has not yet had a significant impact on Indonesia's local millennial customers , there are still many local Indonesian millennial customers not yet aware of the existence of the T3 digital lounge airport and its functions. Moreover, there are still many who don't understand how to use it, even though this unit has been around since 2018 .

\section{Phase III, Disruptive}

In this phase, old markets begin to be disrupted by the development of technology which was originally in the incubation phase as above. Examples of news platforms, news platforms are examples of disruptive innovations that damage the traditional or print media market. Everything has switched to digital media platforms, so that the dissemination of information can be obtained free of charge through digital media. In this phase, PT. Angkasa Pura II (Persero) Soekarno Hatta International Airport through branch communication in socializing $\mathrm{T} 3$ digital airport lounges is to use special event strategies, publications with the use of social media such as Facebook, Instagram and Twitter) and invite social media influencers ( Blogger and YouTuber).

\section{$>$ Phase IV, Demonetization}

This phase in which developing technology has made profit no longer a top priority. One of the trends nowadays is receiving cashback for every transaction on most digital money. Furthermore, in this phase, PT. Angkasa Pura II (Persero) Soekarno Hatta International Airport through digital lounge T3 also contributed to providing services to pay various bills as digital money-paying devices such as providing a vending machine called $\mathrm{m}$-cash. Passengers / public passengers can fill e-toll card balances, buy new etoll cards, buy credit, pay utility bills, water, to the internet and so on.

\section{Phase V, Dematerialization}

In this phase, there is a convergence of the benefits of the old technologies, on a developing technology platform. Like for example, most smartphones are multifunctional because they can listen music, using a flashlight, using a camera and even a digital wallet and various other digital applications are in one smartphone. T3 digital airport lounge is a place that is intended for millennial travelers to be able to enjoy a variety of digital-based services ranging from virtual assistants, digital wayfinding, tourism information, to various other needs. The T3 digital airport lounge is like a one stop service and one stop solution for millennial travelers at Soekano Hatta International Airport. And to further facilitate and pamper Indonesia's local millennial customers, PT. Angkasa Pura II (Persero) Soekarno Hatta International Airport also provides an 
application called Indonesia Airports Apps. This application can be downloaded on iOS and Android, contains a variety of traveler needs such as mobile checkin, express concierge, flight schedules, to information related to public transportation, luggage services to robot dilo, and so on. Through the use of the Indonesia Airports App, in practice making airport services in one hand (airport in your hand).

\section{Phase VI, Democratization}

In this final phase of exponential technology, many people already have the same access in enjoying the technology. For example, like tablets, which used to be only a handful of people who had it when it was first released. Now, even there are shops that open tablet rental services. Furthermore, in this phase, PT. Angkasa Pura II (Persero) Soekarno Hatta International Airport has also provided a place to rent a modem (mobile wifi) for millennial customers who will be traveling abroad so that millennial customers do not have to bother looking for a specific country-specific sim card. Now local Indonesian millennial customers can rent mobile wifi that can be used automatically. Java mifi in the International departure area and Trafy in the T3 digital lounge area.

\section{B. Discussion}

In implementing the implementation of this technology innovation transition strategy, PT. Angkasa Pura II (Persero) Soekarno Hatta International Airport has very high expectations of technological innovation but in its implementation there are still local Indonesian millennial customers who feel they still haven't gained added value due to the sophistication of technological innovation This is because of the ability of local Indonesian millennial customers who are still lacking in following technological developments.

The causes are as follows:

Indonesia's local millennial generation has different individual characteristics, depending on where they are raised, the family's economic and social strata also play an important role in their habit of using sophisticated technology. Seen fromin terms of social stratification (Arifin Noor, 2007) there are 3 (three) levels of social stratification and when associated with this study as follows:

\section{- Top Level Local Millennial}

This level of local millennial can be seen and generally known that they have no financial problems, their finances tend to be stable (economically well established), their educational status is also high, they are technology savvy because they have adapted to digital technology from a small age. Then in carrying out their daily lives they often travel to various places by plane both trips out of town and abroad both on business trips and personal trips. Certainly an understanding of the technology they adopted from other countries they visited, Soekarno Hatta International Airport with digital facilities that have international airports abroad. So in this case the local Indonesian millennial with this top level has absolutely no problem with the transition of technological innovation because they are accustomed to using advanced technology since childhood and even tend to be very able to adapt to the latest technological changes.

\section{- Middle Level Local Millennial}

At this level, local middle-level millennials in the use of the internet are intense enough to carry out their daily lives and carry out their professions in the workforce even though their standard of living is still in the moderate category. In traveling by plane, both business trips and personal trips can be said there are those who travel all the time and some who travel not every time for example in business trips, can also use personal money for young entrepreneurs and can also from companies that assign them to do official trips out of town to overseas so that in terms of education, in terms of profession, financial aspects, middle level local millennials can still be categorized as economically established, no problem with changes in technological innovation,

\section{- Lower Level Local Millennials}

Finally, at this level of local millennial it is difficult to carry out daily life let alone in touch with high technology television alone is not necessarily they have. Even if there are those who come into contact with technology, even then only standard technology such as smartphone technology that suits their budget, and even then it is also a standard technology. For gadget owners both cheap and expensive gadgets, their understanding of internet technology is also just standard. But it is different with high end technology such as those in T3 digital airport lounges where the level of sophistication is above average, habit or habit is needed in using it. For example, lower-level local millennials who have worked abroad though, such as TKI (Indonesian workers) who come from remote geographies, there are still many who do not understand even tend to be confused about how to use public facilities such as those provided by the T3 digital airport lounge. So it is not uncommon to meet local Indonesian millennials at this level at SoekarnoHatta International Airport. Based on interviews with informants that this level of local millennial Indonesia also tends to have the habit of being lazy reading such as lazy reading instructions both directions, as well as instructions on other important digital information that is around Soekarno-Hatta International Airport.

\section{According to (Alvara Research Center, 2018) there are five types of Indonesian millennial generation as follows:}

\section{- Millennial Nerd of $7.4 \%$}

Millennial nerd are those who are included in the millennial group physically and age, but are less sociable. They are actively involved in the creative and technological world, but prefer to be alone and act according to their own wishes. 


\section{- $\quad$ True Millennial 22.7\%}

This true millennial is a true millennial with a style that is always up to date and a smart phone that has been equipped with various advanced features and applications ... This type of millennial is understood by all types of the latest smartphone cameras. They are also very innovative, technology literate, and always ready in the face of change.

\section{- Millennial Mass as much as $41.8 \%$}

For this type of millennial, even though they are millennial, they are fully responsible because in general they are able to use the internet, it is enough to follow the development of gadgets, but active on social media is not as intense as true millennials. Millennial type like this is precisely the most population in Indonesia.

\section{- Millennial Alay as much as $9.3 \%$}

Millennials are millennials who are technologically literate and are very attached to social media life. Millennials like to share status on their instastory as on Instagram about what their experiences are. Worse, the millennial also likes to share a hoax news in various communication media such as whatsapp groups without first finding out the truth of the news.

\section{- Anti-Millennial $18.9 \%$}

Anti millennial are those who are physically and of course age included in the millennial category but their behavior and mindset are still old fashion or conventional, not millennial now. They don't like to interact with social media or the internet.

Based on the types of local Indonesian millennial which has been explained above that the millennial cannot be said to be fully "millennial" because there are still factors that are not fully understood by local Indonesian millennial customers. From interviews with informants and observations in the field, there are still many local Indonesian millennials who are still more likely to ask officers how to use digital facilities rather than trying themselves independently in this case which is included in the category of millennial captives (millennial stuttering) technology) above are types such as anti millennial and mass millennial.

Although the application of T3 digital airport lounge technology innovation has undergone many new changes in public services at the same time so that local Indonesian millennials also feel proud of Indonesian airports because they are no less sophisticated than foreign airports, but in reality that expectations are not always directly proportional to reality. Even though the digital facilities are made so that Indonesian local millennials can feel the sensation of surfing in the digital world independently, to facilitate millennial on the journey, so that Indonesian local millennials have unforgettable experiences.
In accordance with the theory of customer satisfaction (Kotler, 2006) if seen from the case that occurs above that the theory of customer satisfaction can be achieved in synergy if it is also balanced with the ability to understand the technological innovation of local millennial customers in Indonesia. These things can happen because of the limitations of Indonesia's local millennial understanding of higher digital technology and of course the willingness to change to a higher-end digital culture. Because the level of understanding ability of each millennial individual is very diverse it cannot be generalized or generalized. They only have a level of understanding in accordance with their technology alone, so that local Indonesian millennials at certain levels such as the lower millennial level,

\section{CONCLUSIONS AND SUGGESTION}

\section{A. Conclusion}

Based on the findings in this study, the objectives and benefits arising from technological innovation have been very good and have been fulfilled in stimulating other public sectors to emulate and continue to create innovations to provide maximum public service. Although there are still some obstacles that are experienced, there are points that need to be considered in its sustainability, so the researchers make the following conclusions:

Technological innovation strategy that has been carried out by PT. Angkasa Pura II (Persero) Soekarno Hatta International Airport is with a pessimistic approach based on digital information technology, based on social media so that local Indonesian millennials feel welcome. Customer satisfaction has been served because PT. Angkasa Pura II (Persero) Soekarno Hatta International Airport has followed the mainstream, has followed the access to communication that is usually done by Indonesian local millennial and then synergized with the pleasures of local Indonesian millennial habits so that millennials feel there is a common need. In terms of services, information technology PT. Angkasa Pura II (Persero) Soekarno Hatta International Airport has provided its channel by proving it through 6 (six) phases of technological progress that are already very user friendly. In accordance with the vision and mission of PT. Angkasa Pura II (Persero) Soekarno Hatta International Airport, which is easy to manage without restrictions, provides world-class infrastructure and services to support Indonesia's economic development through connectivity between regions and countries and provides a trusted travel experience, consistent and pleasing to all customers with modern technology. But it all also depends on how Indonesia's local millennial capabilities receive and utilize the added value of digital facilities in more innovative ways. 
Expectations of technological innovation PT. Angkasa Pura II (Persero) Soekarno Hatta International Airport very high while the adaptation is still low received by lower level local millennial and certain local level millennial types such as anti millennial type and mass millennial type.

Lower-level local millennials as one of the technology users or connoisseurs of technology should first filter out the technology received by them. In this digital era, of course, millennial level must also be able and responsive to technology, not avoiding technology, let alone rejecting modern technology, because humans must adapt to technology, not technology that adapts to humans, so that humans are ready to face technological challenges going forward. So, as part of modern society, we must also realize how important the use of this sophisticated technology is for the progress of the nation, without having to leave eastern culture.

\section{B. Suggestions}

From what has been explained previously about the types of Indonesian millennial generation that for companies need to understand more deeply the five types of Indonesian local millennial because it is an important step to determine what strategies are right in the future for the target market of Indonesia's local millennial generation. It is not enough to just see that because many of Indonesia's local millennials often travel through the Soekarno-Hatta T3 International Airport, the company assumes that every individual of Indonesia's local millennial is definitely technologically savvy. So that by understanding the profile of each of Indonesia's local millennial segments more specifically, the company will not generalize or generalize technology capabilities in its adoption, both in terms of mindset,

To provide understanding to certain millennials who are technologically illiterate (technologically illiterate) and to educate the entire nation, PT. Angkasa Pura II (Persero) Soekarno Hatta International Airport and its ranks in synergy to continue to provide consistent education by providing tutorials on how to use digital step-by-step lounge facilities on social media with a light, relaxed but polite communication language that is easily understood by all groups. Placing friendly and patient staff in helping to give tutorials directly when the customer is on location.

\section{ACKNOWLEDGMENT}

Special thank you to PT. Angkasa Pura II (Persero) Soekarno Hatta International Airport Branch Communication unit and Airport Digital Lounge T3 unit also thank you to Mercu Buana University, Jakarta Faculty of Communication Sciences for supporting and participating in assisting this research.

\section{REFERENCES}

[1]. Ali, H.2018. Indonesian Millennial Types. Jakarta: Alvara Strategic.

[2]. APJII. 2017. Retrieved June 5, 2020, from https://apjii.or.id/content/read/39/342/ ResultsSurvey-Penetration-and-Behavior-Users-InternetIndonesia-2017.

[3]. Angkasa Pura II. Retrieved June 5, 2020, from Feb 26,2019.https://www.angkasapura2.co.id/id/news/eve nt/pers/214-present-services-digital-zaman-nowlewat-imate-lounge- ap-ii-be-the most innovative company.

[4]. Butterick, K. 2011. Introduction to Public Relations Theory and Practice. Jakarta: PT.Raja Grafindo Persada.

[5]. Clayton, C. 1997. The Innovator's Dilemma When Technologies Cause Great Firms to Fail. Cambridge: Harvard Business School Press.

[6]. Dimandis, P. 2012. Six Phases of Technological Progress Exponential Growth. Retrieved from https://www.diamandis.com/blog/the-6ds.

[7]. Foundation, NC.2013. Retrieved June 4, 2020, from https://www.uschamberfoundation.org.

[8]. Hamid, MA. 2019. Purworejo Regency Transition Strategy From E-Government to Smart City. Journal of Smart Systems. Vol. 02 No.03.

[9]. HM.Arifin, N. 2007. Basic Social Sciences (ISD). Bandung: Loyal Reader.

[10]. Indrajit, RE. 2002. Electronic Government. Yogyakarta: Andi Offset.

[11]. Kasali, R. 2015. Disruption. Jakarta: PT.Pustaka Utama.

[12]. Kotler, P. 2006. Marketing Management. New Jersey: Pearson Prentice Hall.

[13]. Lexy, J. 2006. Qualitative Research Methods. Bandung: Teen Rosdakarya.

[14]. Rhoni, R. 2013. Transition of Indonesian Society Towards Information Society. journal.unair.ac.id.

[15]. Setijaningrum, E. 2009. Public Service Innovation. Surabaya: Medus Aksara Globalindo.

[16]. Sugiyono 2005. Understanding Qualitative Research. Jakarta: CV. Alfabeta. 